
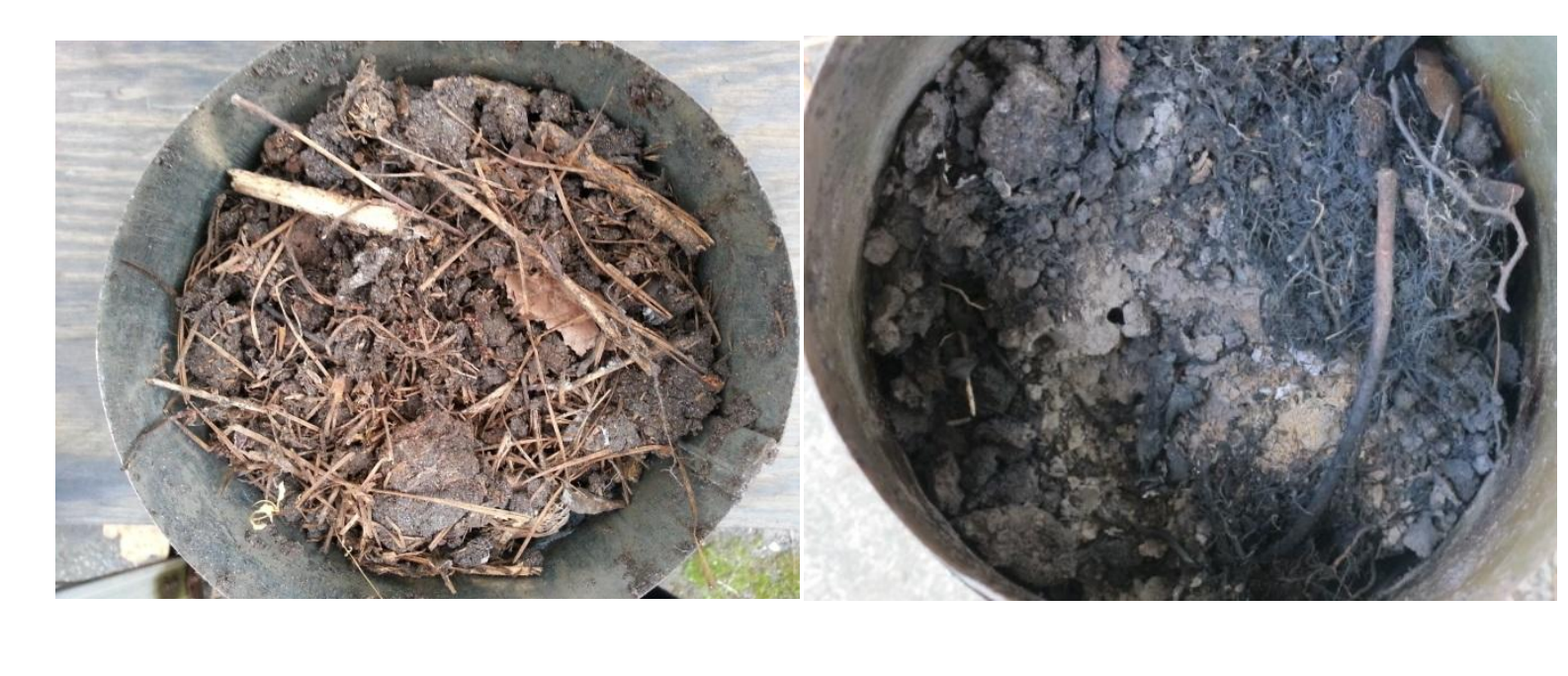

100

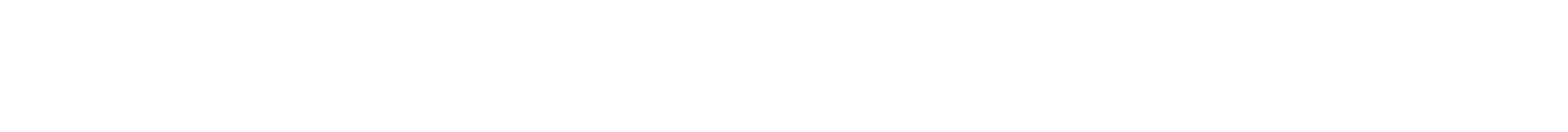
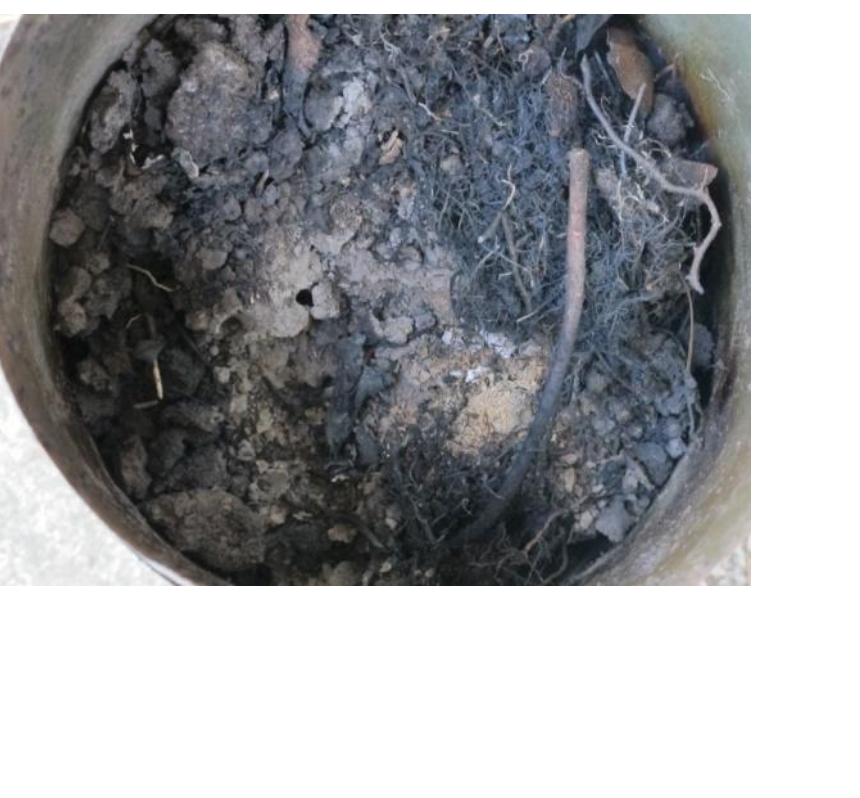


\section{Characterization of Gas and Particle Emissions from Laboratory}

2 Burns of Peat

3 Robert R. Black ${ }^{1,2}$, Johanna Aurell ${ }^{3}$, Amara Holder ${ }^{1}$, Ingrid J.

4 George $^{\mathbf{1}}$, Brian K. Gullett ${ }^{1}$ *, Michael D. Hays ${ }^{1}$, Chris D. Geron ${ }^{1}$, and

5 Dennis Tabor ${ }^{1}$

$7 \quad{ }^{1}$ U.S. Environmental Protection Agency, Office of Research and Development,

8 National Risk Management Research Laboratory, 109 T.W. Alexander Drive,

9 Research Triangle Park, NC 27711

$10{ }^{2}$ Oak Ridge Institute for Science Education, Post-Doctoral Fellow at the U.S. EPA.

$11{ }^{3}$ University of Dayton Research Institute, 300 College Park, Dayton, OH 45469-0141,

$12 *$ Corresponding author, gullett.brian@epa.gov, Phone: 919-541-1534

13

14

15

16

17

\section{Abstract}

Peat cores collected from two locations in eastern North Carolina (NC, USA) were burned in a laboratory facility to characterize emissions during simulated field combustion. Particle and gas samples were analyzed to quantify emission factors for particulate matter $\left(\mathrm{PM}_{2.5}\right)$, organic carbon (OC), elemental carbon, light absorbing carbon, absorption Angstrom exponent, metals, polycyclic aromatic hydrocarbons (PAHs), and polychlorinated dibenzodioxins/dibenzofurans (PCDDs/PCDFs). CO

from the smoldering burns, up to $7 \mathrm{~h}$ in duration, contributed approximately $16 \%$ of the total carbon emitted. Emission factors for black carbon (BC) and light absorbing carbon (UVPM) were considerably lower than those found for forest litter burns.

Emission factors for PCDDs/PCDFs were near published values for forest fuels, at 1-4 ng toxic equivalents (TEQ)/kg carbon burned $(\mathrm{Cb})$. Total PAH concentrations of $\geq 12$ $\mathrm{mg} / \mathrm{kg}$ were higher than published data from biomass burns, but roughly the same in terms of toxicity. Application of these emission factors to the noteworthy 2008 "Evans Road" fire in NC indicates that $\mathrm{PM}_{2.5}$ and PCDD/PCDF emissions from this fire may have been $4-6 \%$ of the annual US inventory and $5 \%$ of the annual OC 1 amount. 
33 Keywords: peat fires, $\mathrm{PCDD} / \mathrm{PCDF}, \mathrm{PAHs}, \mathrm{PM}_{2.5}, \mathrm{CO}$, carbon

\section{Introduction}

37 Peat, a major class of organic soil formed in wetlands, is a vast store of organic

38 carbon, widely distributed from polar to equatorial regions. Peat has high carbon

39 content and is particularly vulnerable to fire when drained (Turetsky et al., 2015).

40 Once ignited peat can burn undetected for very long periods of time (months to years),

41 propagating in a self-sustaining, low intensity, but widely distributed smoldering front

42 through the underground peat layers.

43 Emission factors (EFs) for above-ground fine fuels are well characterized compared to

44 the emissions from peat fires. The major gases produced during biomass burning

45 include $\mathrm{CO}_{2}, \mathrm{CO}$, methane $\left(\mathrm{CH}_{4}\right)$, volatile organic compounds (VOCs), and

46 particulate matter (PM). Emissions of $\mathrm{CH}_{4}, \mathrm{CO}$, and VOCs lead to the photochemical

47 production of ozone and secondary organic aerosols in the troposphere. Light

48 absorbing properties of carbonaceous $\mathrm{PM}$ as well as $\mathrm{CO}_{2}$ and $\mathrm{CH}_{4}$ are of interest for

49 their role as climate forcing agents. Smoldering combustion of surface fuels typically

50 shows distinctive emissions of PM and reduced trace gases (both higher and lower)

51 compared to flaming combustion of the same fuels (Bertschi et al., 2003),

52 underscoring the importance of characterizing smoldering peat combustion.

53 Some characterizations of emissions from peat fires have been performed, showing

54 higher $\mathrm{PM}_{2.5}$ and $\mathrm{CO}$ emissions per unit mass than for surface forest fuels (Geron and

55 Hays, 2013). In addition, since fuel consumption is so high in peat fires, $\mathrm{PM}_{2.5}, \mathrm{CO}$,

56 and $\mathrm{CO}_{2}$ emissions are higher on an area basis compared to other fuel types. The

57 impact of $\mathrm{PM}_{2.5}$ emissions from peat fires is significant, as respiratory and cardiac

58 effects have been demonstrated in laboratory studies (Kim et al., 2014) and

59 epidemiological studies following exposure to peat wildfire smoke (Rappold et al.,

60 2011). 
61 This study determines emission factors for underreported peat combustion pollutants

62 including fine particulate matter, light absorbing particles, polychlorinated

63 dibenzodioxins/dibenzofurans (PCDDs/PCDFs), and polycyclic aromatic

64 hydrocarbons (PAHs).

65

$66 \quad 2$ Materials and Methods

\section{$67 \quad 2.1$ Peat collection and preparation}

68 Peat samples were collected from each of two sites: Alligator River National Wildlife

69 Refuge (AR) and Pocosin Lakes National Wildlife Refuge (PL), both located in

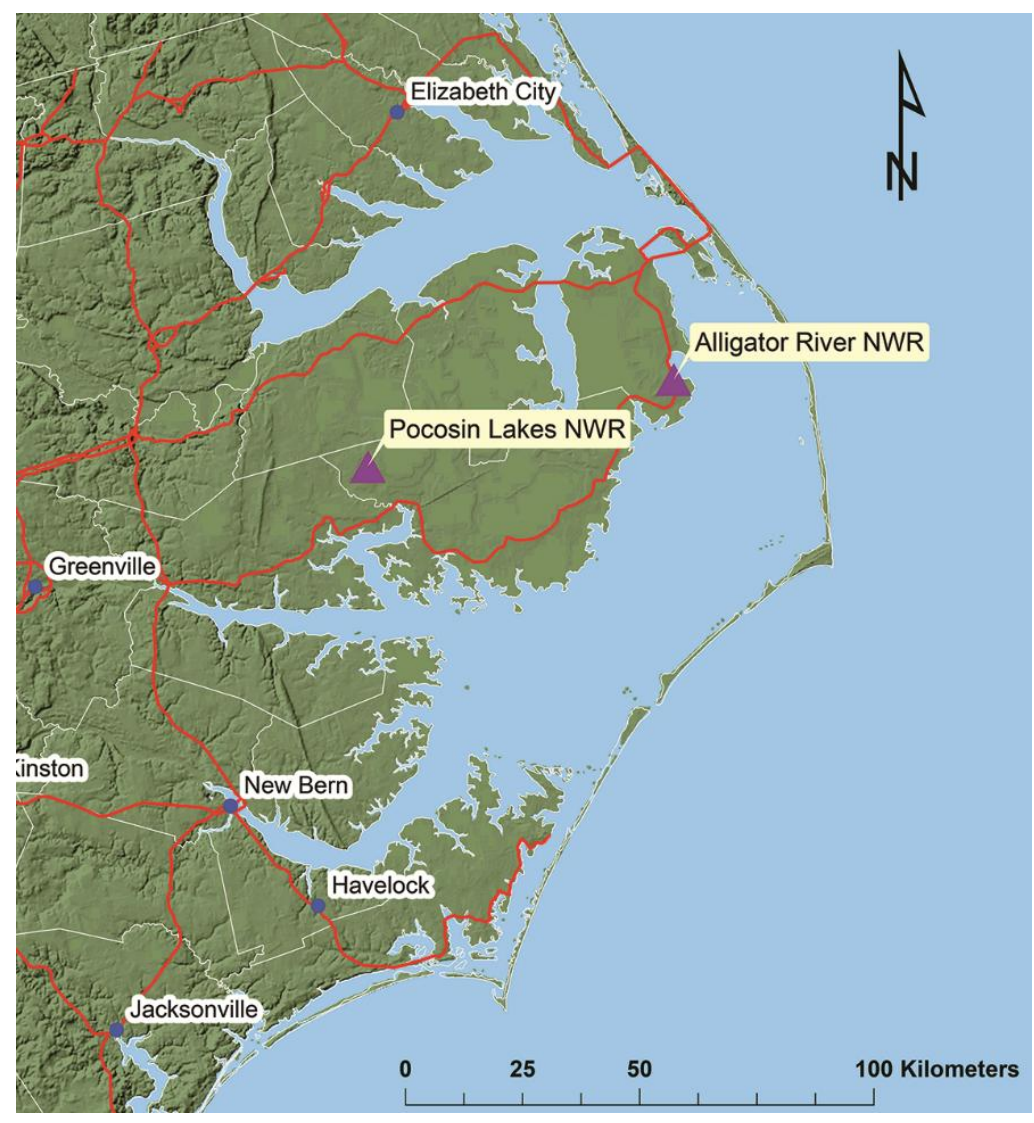

Figure 1. Eastern North Carolina (U.S.A.) locations of peat core samples. Source: USGS, URL:

http://nationalmap.gov/small_scale/atlasftp.html

70 Eastern North Carolina, USA (Figure 1). Each of these locations was the site of

72 extended wildfires in the last ten years that consumed over 16,000 ha each, burning

73 the organic soils to average depths of $\sim 20 \mathrm{~cm}$ and emitting an estimated $0.44 \mathrm{Tg}$ of

$74 \mathrm{PM}_{2.5}$ or $10 \%$ of annual $\mathrm{PM}_{2.5}$ emissions from all U.S. sources emission (Geron and 
75 Hays, 2013). Further characteristics and description of the sites are available in

76 Supporting Information and elsewhere (Geron and Hays, 2013).

78 Peat core samples $150 \mathrm{~mm}$ in diameter and $200-250 \mathrm{~mm}$ deep were collected for 79 transport to an open burn test facility (OBTF) (Black et al., 2011; Gullett et al., 2008).

80 The cores were extracted from organic soil accumulated both near and $3 \mathrm{~m}$ from the

81 base of trees, where consumption was typically deepest during the AR and PL fires.

82 The cores were kept intact and stored vertically by transferring to a $150 \mathrm{~mm}$ diameter

83 galvanized stove pipe and capping with aluminium foil (see Fig. SI-1). All cores were

84 oven dried for $24-36 \mathrm{~h}$ at $110{ }^{\circ} \mathrm{C}$ to enable sustained combustion and to mimic the in

85 situ drying from proximal peat combustion. The cores were stored in plastic tubs for

86 approximately two months before burning. Multiple cores from each site were

87 homogenized before analysis for moisture, carbon, nitrogen, sulfur, chloride, PAH, 88 and PCDD/PCDF content (see Table SI-1).

\section{$92 \quad 2.2$ Burn and sampling procedures}

93 Single peat cores (approximately $1.5-2.5 \mathrm{~kg}$ ) contained within a galvanized stove

94 pipe were placed atop a pan balance (protected by a heat shield) surrounded by a hood

95 enclosure approximately $120 \mathrm{~cm}$ wide x $50 \mathrm{~cm}$ deep x $80 \mathrm{~cm}$ high to concentrate the

96 smoke for sampling (see Figure SI-2). The hood enclosure was located in the $3.9 \times 3.9$

97 x 4.6 m ventilated OBTF, described more fully elsewhere (Black et al., 2011). An

98 induced draft fan refreshed the OBTF volume every 90 seconds, thereby simulating

99 open combustion conditions. The peat cores were ignited briefly $(\sim 30 \mathrm{sec})$ in the

100 center of the upper surface with a propane gas torch.

101 Sampling of the flaming/smoking peat from the hood enclosure commenced after one

102 minute, using continuous emission monitors (CEMs, see Table SI-2) for $\mathrm{CO}_{2}, \mathrm{CO}$,

103 oxygen $\left(\mathrm{O}_{2}\right)$, and total hydrocarbon ( $\left.\mathrm{THC}\right)$ as $\mathrm{CH}_{4}$, as described more fully elsewhere

104 (Woodall et al., 2012). All CEMs were zeroed and spanned at the beginning of each

105 day and rechecked at day's end. For PCDD/PCDF and PAH determinations, smoke

106 was drawn from the outlet of this hood enclosure at a flow rate of approximately 0.6

$107 \mathrm{~m}^{3} \mathrm{~min}^{-1}$ through a $25 \times 20 \mathrm{~cm}$ quartz filter (see Fig. SI-3), a cylindrical pre-cleaned 
108 polyurethane foam (PUF) plug (7.5 cm diameter), and XAD-2 resin in series,

109 consistent with U.S. EPA sampling method TO-9A (EPA, 1999). Collection of at least

$11010-15 \mathrm{~g}$ of carbon as $\mathrm{CO}_{2}$ was targeted to minimize non-detects among the $17 \mathrm{Cl}$ -

111 substituted PCDD/ PCDF congeners in the toxic equivalency (TEQ) measure.

$112 \mathrm{PM}_{2.5}$ was sampled from the enclosure hood using impactors with both

113 polytetrafluoroethylene (PTFE, pore size of $2.0 \mu \mathrm{m}$ ) and quartz filters. Both samplers

114 used a Leland Legacy sample pump (SKC Inc., Pittsburgh, PA, USA) with a constant

115 airflow of $10 \mathrm{~L} / \mathrm{min}$. The Leland Legacy sample pumps were calibrated with a

116 Gillibrator Air Flow Calibration System (Sensidyne LP, St. Petersburg, FL, USA) as

117 the primary standard. An internal flow sensor on the Leland pump measured flow

118 directly and acted as a secondary standard to maintain the set flow constant. Four

119 sampling inlets for the CEMS were located above the $\mathrm{PM}_{2.5}$ and OC/EC impactors

120 (see Fig. SI-2).

121 Fires were typically self-sustaining; an initial 1-3 min flaming phase after propane

122 torch ignition was followed by prolonged smoldering. In two cases, the peat had to be

123 relit. Burns were comprised of an initial and final period of sampling, each period

124 approximately 3-4 h in duration and designated as "0-3h" and " $3-7 \mathrm{~h}$ ". Sampling was

125 typically 3 hours followed by sorbent and filter changes and then an additional 4 to

1264.5 hours sampling, after which smoldering was still evident.

\section{$128 \quad 2.3$ Sample analysis}

129 2.3.1 PM, metals, and organic carbon/elemental carbon

$130 \mathrm{PM}_{2.5}$ samples were collected on quartz and pre-weighed PTFE filters in $\mathrm{PM}_{2.5}$

131 impactors. Gravimetric determination of PM was by microbalance (resolution 0.01

$132 \mathrm{mg}$ ). Metal analysis on $\mathrm{PM}_{2.5}$ PTFE filters was carried out using a wavelength-

133 dispersive X-ray fluorescence spectrophotometer (PANalytical PW2404,

134 Westborough, MA). Thermal-Optical Analysis (TOA) using a modified NIOSH 5040

135 method was performed to determine the organic carbon (OC), elemental carbon (EC),

136 and total carbon (TC) content in the PM collected (Khan et al., 2012). 


\section{$137 \quad 2.3 .2 \quad$ BC and UVPM}

138 Black carbon (BC) and light absorbing organic compounds were sampled using a

139 portable, filter ticket-based, continuous, optical aethalometer technique (Models AE51

140 and AE52, Aethlabs, San Francisco, CA, USA) based on light attenuation at $880 \mathrm{~nm}$

141 (BC) and $370 \mathrm{~nm}$ (UVPM). Enhanced aerosol absorption in the UV portion of the

142 spectrum for biomass burning emissions is indicative of the presence of light

143 absorbing organic carbon, i.e. brown carbon. Brown carbon emissions are quantified

144 by the AE-52 as UVPM, which is defined as the BC mass equivalent excess

145 attenuation at $370 \mathrm{~nm}$ over that ascribed to BC. For comparison with other

146 measurement methods (Ajtai et al., 2011), optical attenuation attributed to brown

147 carbon is also reported as an absorption angstrom exponent, AAE:

$148 \quad \mathrm{AAE}=-\ln [(880 / 370) *(1+\mathrm{UVPM} / \mathrm{BC})] / \ln (370 / 880)$

149

150

151

152

153

154

155

156

157

158

159 PAHs were cleaned up according to U.S. EPA Method TO-13 (1999) and quantified

160 using an internal standard method based on Method 8270 of SW-846 (EPA, 2007).

161 Samples were analyzed using a Hewlett-Packard gas chromatograph 5890 Series II

162 with a DB-5 $60 \mathrm{~m} \times 0.25 \mathrm{~mm} \times 0.25 \mu \mathrm{m}$ column (Agilent/J\&W Scientific) connected

163 to a Hewlett Packard 5972 mass spectrometer. PAH emission factors were evaluated

164 using toxic equivalent factors (TEFs) relative to the benzo(a)pyrene toxicity

165 equivalent (B(a)P-TEQ) (Larsen, 1998). 
169 Emission factors were calculated using the carbon mass balance approach (Ward et

170 al., 1979) as is common for sources of open burning (Black et al., 2011). This method

171 calculates the target compound mass in ratio to the carbon mass burned from

172 concurrently collected $\mathrm{CO}, \mathrm{CO}_{2}$, and $\mathrm{CH}_{4}$ measurements. $\mathrm{PM}$ carbon was neglected as

173 it amounted, on average, to less than $0.1 \%$ of the carbon emitted. These values of

174 pollutant mass per mass of carbon burned, along with the carbon percentage in the raw

175 peat (see Table 1), were used to derive emission factors in terms of mass of target

176 compound per dry weight mass of peat biomass burned in $\mathrm{g} / \mathrm{kg}$.

\section{Results and Discussion}

179 Four 5 to $7 \mathrm{~h}$ (typical) burns were conducted on $2.1 \mathrm{~kg}(\mathrm{SD}=0.6 \mathrm{~kg})$ peat samples

180 from each of the two sites. The total gravimetric mass loss averaged $0.176 \mathrm{~kg}(\sim 10 \%$

181 of the initial weight) for the AR peat and about $0.163 \mathrm{~kg}(\sim 7 \%)$ for the PL. Analyses

182 of six peat samples from each source indicated similar carbon contents but

183 considerable variability: $28 \%$ (10\% s.d.) for AR and 30\% (8\% s.d.) for PL. These peat

184 samples had distinctively lower $\mathrm{C}$ content than previous cores from this same general

185 area (Geron and Hays, 2013), reflected in higher ash values: 44\% (10\% s.d.) for AR

186 and $62 \%$ (12\% s.d.) for PL. Assuming half of this mass loss was attributed to loss of

187 carbon from biomass, then $19 \%$ of the AR carbon and $11 \%$ of the PL carbon,

188 respectively, would have been released during the burn, indicating an upper limit on

189 the extent of the carbon burned. The average mass loss rate over the course of the

190 burn for AR and PL was $0.92 \mathrm{~g} \mathrm{~min}^{-1}$ and $0.52 \mathrm{~g} \mathrm{~min}^{-1}$, respectively.

191 The run-averaged modified combustion efficiency, $\mathrm{MCE}\left(\Delta \mathrm{CO}_{2} /\left(\Delta \mathrm{CO}_{2}+\right.\right.$

$192 \Delta \mathrm{CO})$ )(Ward and Radke, 1993) ranged between 0.80 and 0.88 for the individual AR

193 and PL samples, with no notable distinction between the two peat sources for the 0-3

$194 \mathrm{~h}$ and 3-7 $\mathrm{h}$ samples. These MCE values are much lower than the values found for

195 over 50 laboratory combustion tests of field-gathered biomass (none were peat)

196 averaging over 0.94 (Hosseini et al., 2013), but are consistent with lower MCE values

197 for peat burns found elsewhere (Christian et al., 2003; Liu et al., 2014; May et al.,

198 2014; Rein et al., 2009; Stockwell et al., 2014; Yokelson et al., 1997). 
199 The temporal combustion characteristics for the peat burns were distinctive from 200 those observed in the same burn facility with mixed pine understory biomass (Aurell 201 and Gullett, 2013). Figure 2 shows the evolution of $\Delta \mathrm{CO}, \Delta \mathrm{CO}_{2}$, and $\mathrm{MCE}$

202 throughout the beginning of an illustrative PL peat burn in comparison with the pine

203 burn. The $\Delta \mathrm{CO}_{2}$ and $\Delta \mathrm{CO}$ concentrations for the PL peat burn decreased steadily

204 after a brief (<60 s) flaming period while the MCE remained relatively constant

205 throughout. In contrast, the forest litter showed declining MCE and gases throughout 206 its burn, reflective of a gradual transition from flaming to smoldering.

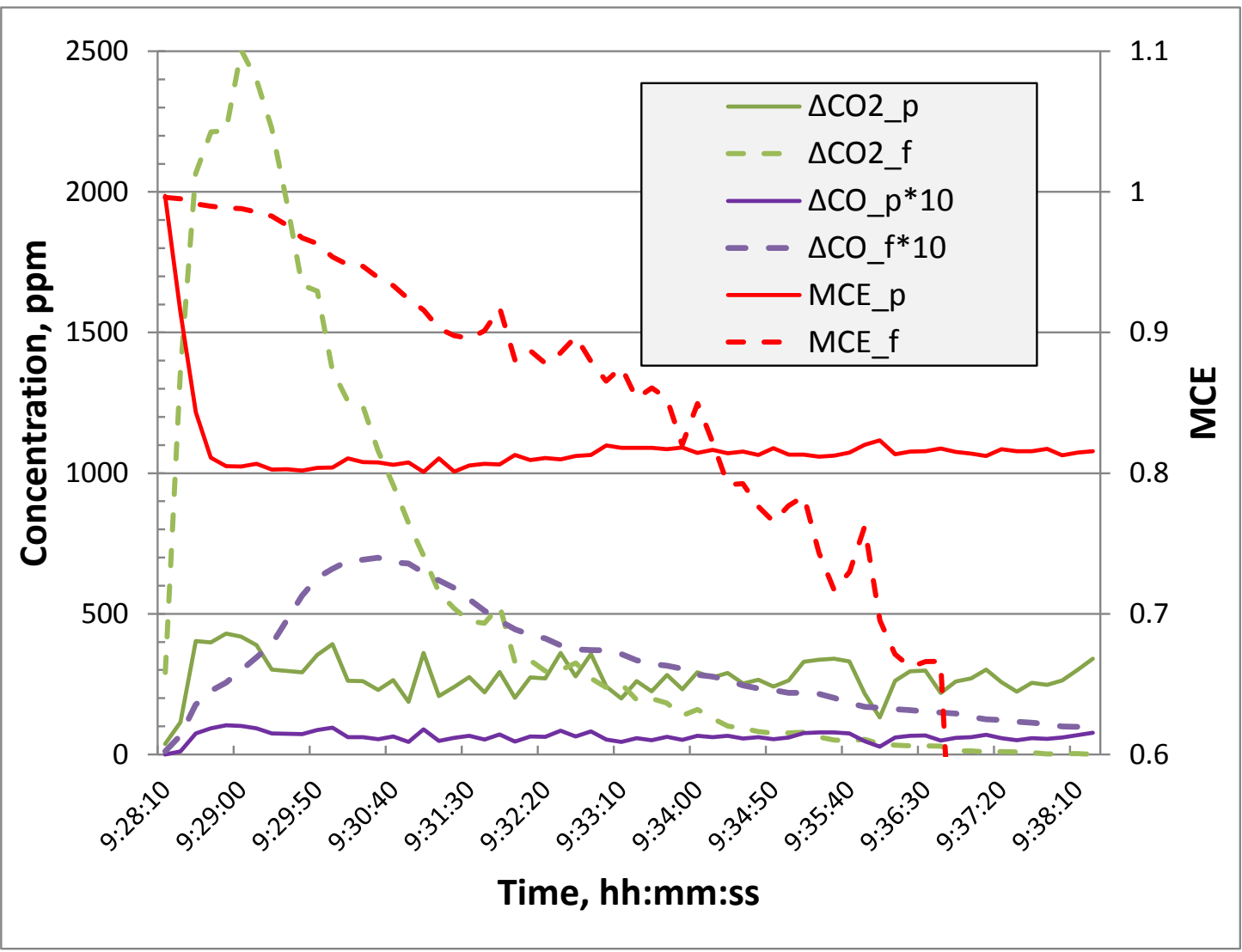

210 Figure 2. Comparison of concentration and modified combustion efficiency profiles

211 for peat burns (-p, solid lines) (this work) and forest litter burns (-f, dashed

212 lines)(Aurell and Gullett, 2013). 
$216 \quad 3.1$ Summary Emission Factors

217

218 Table lincludes the average emission factors and standard deviations from the burn

219 tests. A breakdown of these results follows in the sections below.

220 
221 Table 1. Summary Emission Factors for Peat Burns from Alligator River (AR) and Pocosin Lakes (PL) National Wildlife Refuges.

\begin{tabular}{|c|c|c|c|c|c|c|c|c|c|}
\hline \multirow{5}{*}{$\mathrm{PM}_{2.5}$} & \multirow{4}{*}{$\begin{array}{l}\text { Units } \\
\mathrm{g} / \mathrm{kg}\end{array}$} & \multicolumn{4}{|c|}{ AR } & \multicolumn{4}{|c|}{ PL } \\
\hline & & \multicolumn{2}{|c|}{ Avg } & Avg & $\mathrm{sd}$ & \multicolumn{2}{|c|}{ Avg } & Avg & $\mathrm{sd}$ \\
\hline & & \multirow{2}{*}{$\begin{array}{c}0-3 \mathrm{~h} \\
10.4\end{array}$} & \multirow{2}{*}{$\begin{array}{c}3-7 \mathrm{~h} \\
3.7\end{array}$} & \multicolumn{2}{|c|}{$0-7 \mathrm{~h}$} & $0-3 \mathrm{~h}$ & $3-7 \mathrm{~h}$ & \multicolumn{2}{|c|}{$0-7 \mathrm{~h}$} \\
\hline & & & & 7.1 & 5.6 & 10.8 & 1.0 & 5.9 & 6.7 \\
\hline & $\mathrm{g} / \mathrm{kg} \mathrm{Cb}$ & 36.8 & 13.2 & 25 & 20 & 36.5 & 3.4 & 20 & 22.6 \\
\hline $\mathrm{CO}$ & $\mathrm{g} / \mathrm{kg}$ & 111 & 104 & 108 & 20 & 129 & 116 & 122 & 14 \\
\hline $\mathrm{CO} / \mathrm{C}$ & $\mathrm{g} / \mathrm{g}$ & 0.39 & 0.37 & 0.38 & 0.07 & 0.44 & 0.39 & 0.41 & 0.05 \\
\hline $\mathrm{CO}_{2}$ & $\mathrm{~g} / \mathrm{kg}$ & 865 & 856 & 861 & 112 & 941 & 902 & 922 & 47 \\
\hline MCE & Unitless & 0.86 & 0.86 & 0.86 & 0.02 & 0.82 & 0.83 & 0.83 & 0.02 \\
\hline $\mathrm{BC}$ & $\mathrm{g} / \mathrm{kg}$ & 0.08 & 0.04 & 0.07 & 0.04 & 0.06 & 0.06 & 0.06 & 0.01 \\
\hline UVPM & $\mathrm{g} / \mathrm{kg}$ & 0.19 & 0.11 & 0.15 & 0.11 & 0.16 & 0.19 & 0.18 & 0.05 \\
\hline BC/UVPM & Unitless & 0.43 & 0.38 & 0.45 & & 0.35 & 0.29 & 0.32 & \\
\hline $\mathrm{OC}$ & $\mathrm{g} / \mathrm{kg}$ & 8.7 & 3.3 & 6.3 & 4.1 & 5.6 & 2.1 & 4.3 & 4.1 \\
\hline $\mathrm{EC}$ & $\mathrm{g} / \mathrm{kg}$ & 0.088 & 0.017 & 0.052 & 0.057 & 0.103 & 0.061 & 0.082 & 0.091 \\
\hline OC/EC & Unitless & 99 & 194 & 121 & & 54 & 143 & 52 & \\
\hline $\mathrm{BC} / \mathrm{EC}$ & Unitless & 14 & 3.3 & 1.9 & & 0.63 & 2.1 & 0.97 & \\
\hline $\mathrm{AAE}$ & Unitless & 2.03 & 2.28 & 2.15 & 0.61 & 2.13 & 2.47 & 2.30 & 0.44 \\
\hline $\mathrm{THC}$ as $\mathrm{CH}_{4}$ & $\mathrm{~g} / \mathrm{kg}$ & 31.0 & 24.1 & 30.2 & 7.2 & 31.8 & 33.1 & 32.4 & 14.2 \\
\hline PAHs (16) & $\mathrm{mg} / \mathrm{kg}$ & 70 & 8.1 & 16 & 8.9 & 22 & 6.1 & 14 & 9.0 \\
\hline & mg TEQ/kg, B[a]P eq. & 0.82 & 0.04 & 0.16 & 0.05 & 0.20 & 0.09 & 0.15 & 0.07 \\
\hline $\mathrm{PCDD} / \mathrm{PCDF}$ & $\mathrm{ng} / \mathrm{kg}$ & 310 & 240 & $510^{1}$ & 280 & 970 & 160 & 560 & 490 \\
\hline & ng TEQ/kg & 1.9 & 2.2 & $2.6^{1}$ & 1.2 & 3.1 & 0.6 & 1.9 & 1.6 \\
\hline & ng TEQ/kg Cb & 2.5 & 2.9 & 3.4 & 1.6 & 2.9 & 0.6 & 1.8 & 1.4 \\
\hline
\end{tabular}


$223{ }^{1}$ The 0-7 $\mathrm{h}$ average is higher than the 0-3 $\mathrm{h}$ and 3-7 $\mathrm{h}$ averages because two more single, undivided 0-7 $\mathrm{h}$ samples were included. 


\section{$225 \quad 3.2 \quad \mathbf{P M}_{2.5}$}

226 Minimal difference was observed between the $\mathrm{PM}_{2.5}$ emission factors from each peat

227 type (see Table 1), given the variability in burn results. The average $0-7 \mathrm{~h} \mathrm{PM}_{2.5}$

228 emission factor for both peats is $6.6 \pm 5.9 \mathrm{~g} \mathrm{PM}_{2.5} / \mathrm{kg}$ biomass burned. Literature

229 values for peat $\mathrm{PM}_{2.5}$ emission factors are all higher than observed in this work with

230 values of 33 and $44 \mathrm{~g} / \mathrm{kg}$ biomass for German peat (Iinuma et al., 2007) and $35 \mathrm{~g} / \mathrm{kg}$

231 for $\mathrm{PM}_{1}$ from Indonesean peat (May et al., 2014). Previous sampling of ground fires

232 at AR and PL (Geron and Hays, 2013) resulted in PM $_{2.5}$ emission factors of 34-66

$233 \mathrm{~g} / \mathrm{kg}$. These higher emissions may partly be reflective of the large distinctions in

234 carbon content (54-60\% in their work and 28-30\% in our work) and ash content (13-

$23517 \%$ in their work and $44-62 \%$ in our work). This is likely due to our samples being

236 gathered from areas that experienced previous fires, suggesting significant differences

237 in the peat sources despite collection from the same burned areas. Another potentially

238 important difference with others' results is that our sampling times of up to $7 \mathrm{~h}$ were

239 much longer than the sampling times of $57 \mathrm{~min}$ reported by others (Iinuma et al.,

240 2007). The average $\mathrm{PM}_{2.5}$ emission factors in this work were three to ten times higher

241 for the initial three hour sampling period than for the final period for both peat types

242 (Table 1). To look at the early burn performance, we examined two samples from the

243 top $2 \mathrm{~cm}$ of each $\sim 20 \mathrm{~cm}$ core type for carbon content and found no distinction with

244 the whole sample values that could explain this $\mathrm{PM}_{2.5}$ variation. This suggests that the

245 emissions at longer sampling times may be a product of reaction regimes that were

246 controlled by different mechanisms (e.g., diffusion) than at the burn onset (Bertschi

247 et al., 2003).

\subsection{Inorganics in PM}

250 Metal concentrations on $14 \mathrm{PM}_{2.5}$ PTFE filters were determined by XRF (see Table

251 SI-3). The most abundant elements in the filter-collected PM mass aside from carbon

252 and oxygen were sulfur and chlorine, where the sulfur fraction averaged over four

253 times higher for AR peat (1.96\%) than for PL peat $(0.46 \%)$. Some filter elements

254 commonly found in soil (e.g., $\mathrm{Si}, \mathrm{Fe}, \mathrm{Ca}, \mathrm{Sr}, \mathrm{Cu}, \mathrm{Cr}$, and $\mathrm{Al}$ ) were observed after

255 background corrections. The resulting $\mathrm{Cl}$ emission factors are 0.011 and $0.004 \mathrm{~g} \mathrm{Cl} / \mathrm{kg}$

256 biomass burned ( 0.051 and $0.012 \mathrm{~g} \mathrm{Cl} \mathrm{kg}^{-1}$ carbon burned $\left(\mathrm{C}_{\mathrm{b}}\right)$ ) for $\mathrm{AR}$ and PL, 
257 respectively. These values, when compared against the raw peat $\mathrm{Cl}$ analyses, are 258 consistent with data from a variety of fuels (Christian et al., 2003; Hosseini et al., 259 2013). Peat from AR had a higher chlorine concentration than peat from PL, at 460 260 and $190 \mathrm{mg} / \mathrm{kg}$, respectively, which may be due to its proximity to the Atlantic Ocean 261 and subsequent salt water intrusion during storm events. However, the top $2 \mathrm{~cm}$ of 262 the peat cores had lower $\mathrm{Cl}$ content, at 180 and $70 \mathrm{mg} / \mathrm{kg}$ for AR and PL, respectively. 263 Sulfur was detectable at AR $(0.12 \mathrm{mg} / \mathrm{kg})$ but was below the detection limit at PL $264(<0.05 \mathrm{mg} / \mathrm{kg})$.

\subsection{OC, EC, BC, and UVPM}

268 The overall AR OC emission factor, $6.3 \pm 4.1 \mathrm{~g} / \mathrm{kg}$, was indistinguishable from the 269 overall emission factor of PL, $4.3 \pm 4.1 \mathrm{~g} / \mathrm{kg}$. For both peat sources, the initial $0-3 \mathrm{~h}$ 270 samples had approximately two to three times higher OC emission factors than the 271 final 3-7h samples, similar to observed changes in $\mathrm{PM}_{2.5}$ mass emission factors. EC

272 emission factors for AR and PL were $0.05 \mathrm{~g} / \mathrm{kg}$ and $0.08 \mathrm{~g} / \mathrm{kg}$, respectively, much 273 lower than reported for biomass burns from others (Hays et al., 2002). Our averaged $274 \mathrm{OC} / \mathrm{EC}$ ratios were 115 and 87 for AR and PL, respectively, a bit lower than the value 275 of 151 for Indonesian peat (Christian et al., 2003). However, the OC/EC ratios from 276 this work were substantially higher than the OC/EC ratios in the range of 1.4 to 14 277 from more recent peat burning studies in the laboratory (Iinuma et al., 2007; See et al., 278 2007). This wide variation in reported OC/EC ratios may be influenced by different 279 sample collection procedures, where values are expected to change with downwind 280 travel due to continued plume reactions. Associations of OC emission factors with 281 MCE were previously found to be negative with laboratory burns of multiple biomass 282 species (Hosseini et al., 2013). EC correlations with MCE were minimal (Hosseini et 283 al., 2013) or weakly positive (McMeeking et al., 2009), while prescribed biomass 284 burns have found positive correlations with light absorbing species (Aurell and 285 Gullett, 2013). 
287 Average BC emission factors

288 for the AR and PL sources

289 (Table 1) were essentially

290 equivalent at $0.07 \mathrm{~g} / \mathrm{kg}(0.25 \mathrm{~g}$

$291 \mathrm{~kg}^{-1} \mathrm{C}_{\mathrm{b}}$ and $0.06 \mathrm{~g} / \mathrm{kg}(0.20 \mathrm{~g}$

$292 \mathrm{~kg}-1 \mathrm{Cb}$ ) respectively, while

293 the emission factors for UVPM

294 show some separation: 0.15

$295 \mathrm{~g} / \mathrm{kg}$ versus $0.18 \mathrm{~g} / \mathrm{kg}$. The

296 value for BC can be compared

297 with the values obtained by

298 others (May et al., 2014), who

299 obtained $0.01 \mathrm{~g} / \mathrm{kg}$ for

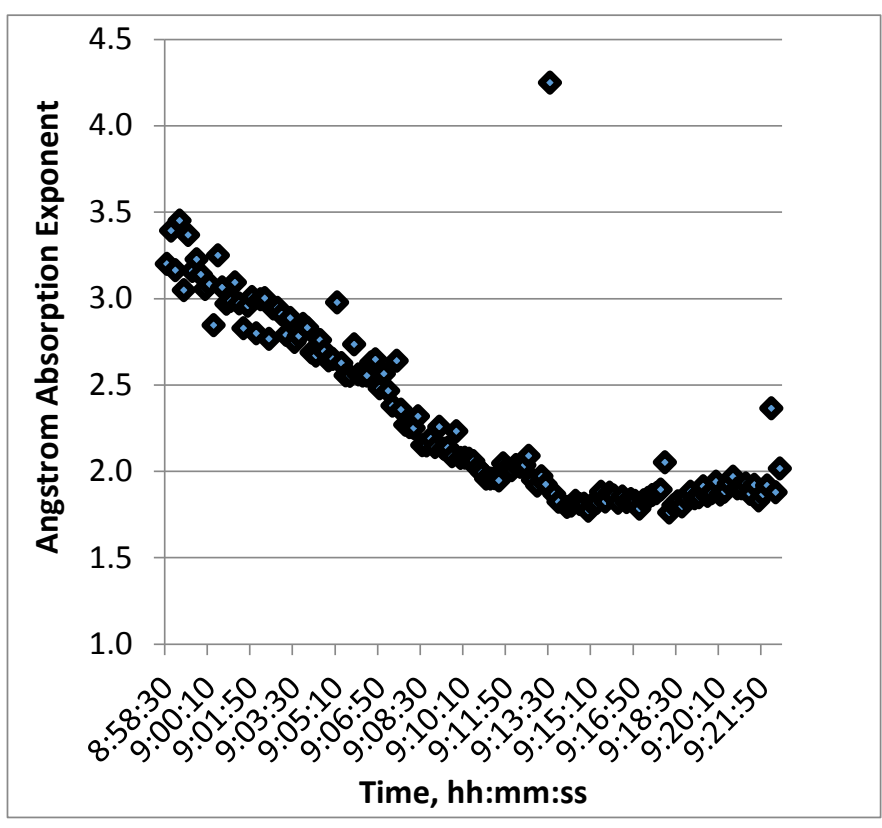

Figure 3. Angstrom Absorption Exponent through the initial period of a representative peat burn, PL, 0-3 h.

300 Indonesian peat. The much

301 larger BC EF measured here compared to May et al.(May et al., 2014) may be partly

302 due to the different BC measurement approach used in each study, which can result in

303 a difference of a factor of 2 (Yelverton et al., 2014). A typical AAE curve is shown in

304 Figure 3, indicating the decline in attenuation attributed to brown carbon with

305 continued smoldering. AAE values were slightly higher for PL than for AR with

306 overlap in the one standard deviation range. These AAE values are somewhat lower

307 than the values that have previously been reported for laboratory combustion of peat,

$3083-6$ (Liu et al., 2014). However, given the wider wavelength range (370 - 880 vs.

$309405-781$ ) used to calculate AAE and the tendency for AAE to decrease when

310 including wavelengths in the IR, the lower values are reasonable. These values are

311 supported by results of Chen et al. (Chen et al., 2010)who observed low AAE ( 1.5)

312 for this wavelength range applied to smoldering combustion of moist fuels.

313 Additionally, AAE tends to increase with decreasing MCE, therefore the higher AAE

314 measured by Liu et al. are consistent with the lower MCEs they observed for peat.

315 BC and UVPM values for AR were higher during period 0-3h than 3-7h, while little

316 distinction was noted for the PL. For both peat sources, the UVPM/BC ratio is about

$317 \quad 2-3: 1$. 
319 Whole-burn BC and UVPM values from field forest burns and laboratory burns are

320 typically greater than $0.5 \mathrm{~g} / \mathrm{kg}$ (approximately $1 \mathrm{~g} \mathrm{~kg}^{-1} \mathrm{C}_{\mathrm{b}}$ ) (Aurell and Gullett, 2013),

321 higher than the peat results observed here (Table 1). Comparison of BC/UVPM ratios

322 for peat and forest litter burn profiles with illustrative data (Figure 4, logarithmic

323 scale) shows that UV absorption in forest fires is dominated by the BC whereas in the

324 peat system, absorption is dominated by UVPM. This observation is consistent with

325 greater BC production from the flame-dominant forest litter burn and the larger OC

326 content of emissions from the peat smoldering.

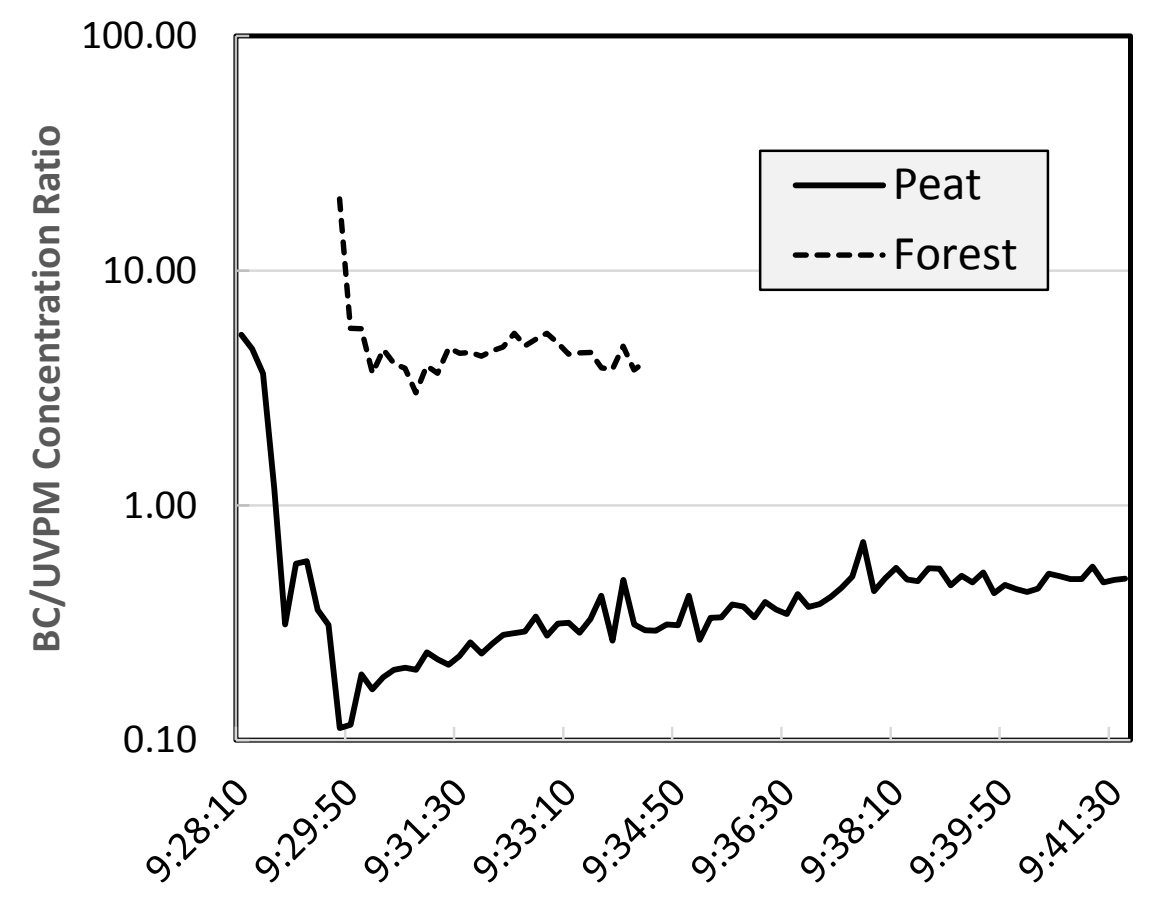

Time hh:mm:ss

328 Figure 4. Comparison of BC/UVPM ratios in peat (this work, representative data) and 329 forest litter burns ((Aurell and Gullett, 2013))

332 Overall, BC and UVPM emission factors and MCEs for peat are significantly lower

333 than for the forest biomass and are consistent with others' findings (McMeeking et al.,

334 2009). Both the BC and UVPM values appear independent of MCE, at the lower

335 MCE range observed for peat combustion (Figure 5). However, laboratory burns

336 (Aurell and Gullett, 2013) with forest biomass that allow continuous determination of

337 MCE values rather than whole-run composite MCE determinations show BC and

338 UVPM emission factors of 1.0 and $0.4 \mathrm{~g} \mathrm{~kg}^{-1} \mathrm{C}_{\mathrm{b}}$, respectively, when the burn profiles 
339 are at an MCE of 0.85 (Figure 3C (Aurell and Gullett, 2013)), suggesting that the

340 lower BC and UVPM values observed in these tests are typical for smoldering

341 conditions, regardless of the biomass type. The distinctions in peat emissions versus

342 pine litter burns are underscored by a visual comparison of the $\mathrm{PM}_{2.5}$ mass collected

343 on the filters. The peat filters are a deep yellow (Fig. SI-3), reflecting the relatively

344 high organic to black carbon content while conversely, the filters from pine burns are

345 black to gray, depending on the combustion efficiency.

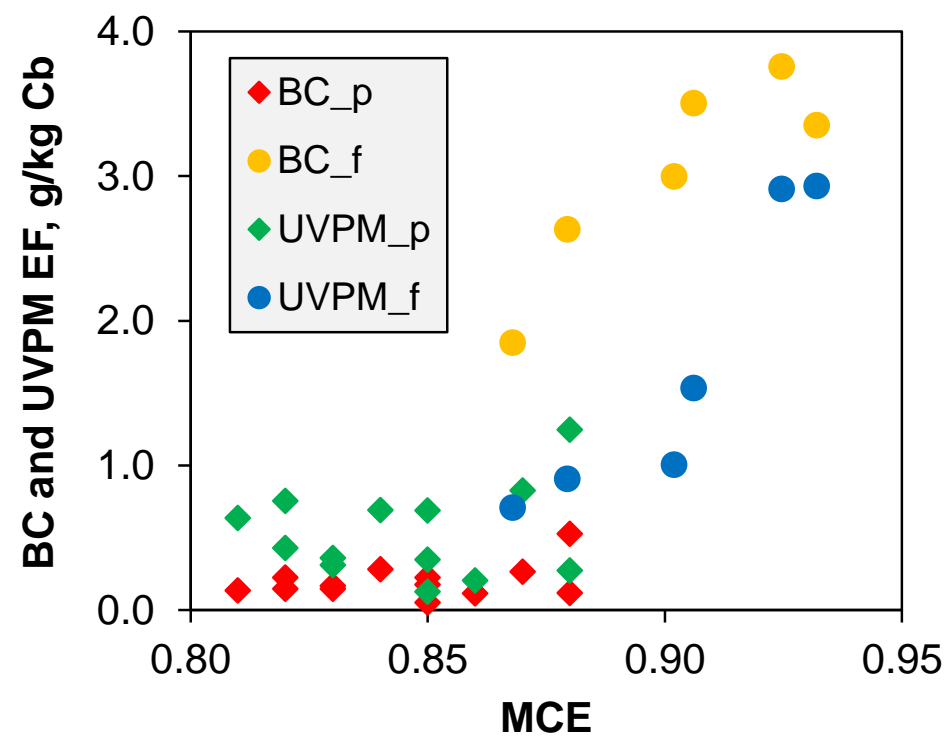

347 Figure 5. Run-averaged BC and UVPM emission factors compared to combustion 348 quality (MCE) from peat burns (diamonds, this work) and forest litter burns (circles, 349 Aurell \& Gullett, 2013).

\subsection{PAHs}

354 PAH emissions (Table 2) from combined gas and particle samples were dominated by

355 naphthalene, fluorene, and phenanthrene, with all three compounds exceeding 9

$356 \mathrm{mg} / \mathrm{kg} \mathrm{C} \mathrm{b}_{\mathrm{b}}$ for both AR and PL. A more extensive analysis of particle phase PAHs

357 beyond the 16 "EPA PAHs," is reported elsewhere (George, 2015). The five most

358 prevalent PAHs are also found in the top eight PAHs for pine combustion

359 measurements (Jenkins et al., 1996). The total PAH emissions (sum of 16 compounds) 
360 of $16.0 \pm 8.9 \mathrm{mg} / \mathrm{kg}$ for AR and $14 \pm 9.0 \mathrm{mg} / \mathrm{kg}$ for PL are similar to each other and

361 consistent with values (18 and $25 \mathrm{mg} / \mathrm{kg}$ ) for peat from (Iinuma et al., 2007).

362 There is relative similarity in the PAH compositional profile and emission factors for 363 the two sites, although the PAH total of PL was twice the PAH total of AR (Table 2).

364 The burn emissions were over 100 times greater than the concentrations in the raw

365 peat analyses (on a $\mathrm{C}$ basis), confirming that the emissions were not solely due to 366 vaporization but were primarily formed during combustion. The initial period of the

367 burns had four to nine times higher PAH emission factors compared to the final

368 period of the burns for both peat types, which was consistent with observed trends in

$369 \mathrm{PM}_{2.5}$ and $\mathrm{OC}$ emission factors.

370 The toxic equivalency factors were applied to the 12 carcinogenic PAHs to derive an

371 overall hazard level. Our B[a]P equ. toxicity values, $0.12 \pm 0.04 \mathrm{mg} / \mathrm{kg}$ and $0.16 \pm 0.08$

$372 \mathrm{mg} / \mathrm{kg}$ for AR and PL, respectively, are above values reported for Indonesian and

373 German peat ( 0.06 mg B[a]P equ. $\mathrm{kg}^{-1}$ for both sources) (Iinuma et al., 2007).

374 However, our values are more consistent with values calculated from other biomass

375 burns in the range of 0.1 to $0.57 \mathrm{~B}$ [a]P equ./kg (Dhammapala et al., 2007; Jenkins et

376 al., 1996). The initial 0-3h emissions were 2 to 20 times more carcinogenic (Table 2)

377 than the emissions in the $3-7 \mathrm{~h}$ samples, and the AR emissions were more than three

378 times as carcinogenic as those from PL. 
PAH Concentrations

$\mathrm{mg} \mathrm{kg}^{-1}$ carbon. $\mathrm{N}=3$

Naphthalene

Acenaphthylene

Acenaphthene(CCC)

Fluorene

Phenanthrene

Fluoranthene(CCC)

Pyrene

Benzo(a)anthracene

\section{Chrysene}

Benzo(b)fluoranthene

Benzo(k)fluoranthene

Benzo(a)pyrene(CCC)

Indeno(1,2,3-cd)pyrene

Dibenz(a,h)anthracene

Benzo(ghi)perylene

Total

B[a]P eqs., mg/kg\#

$\mathrm{B}[\mathrm{a}] \mathrm{P}$ eqs, $\mathrm{mg} / \mathrm{kg} \mathrm{Cb}$

$381 \mathrm{~B}[\mathrm{a}] \mathrm{P}$ eqs, $\mathrm{mg} / \mathrm{kg}$

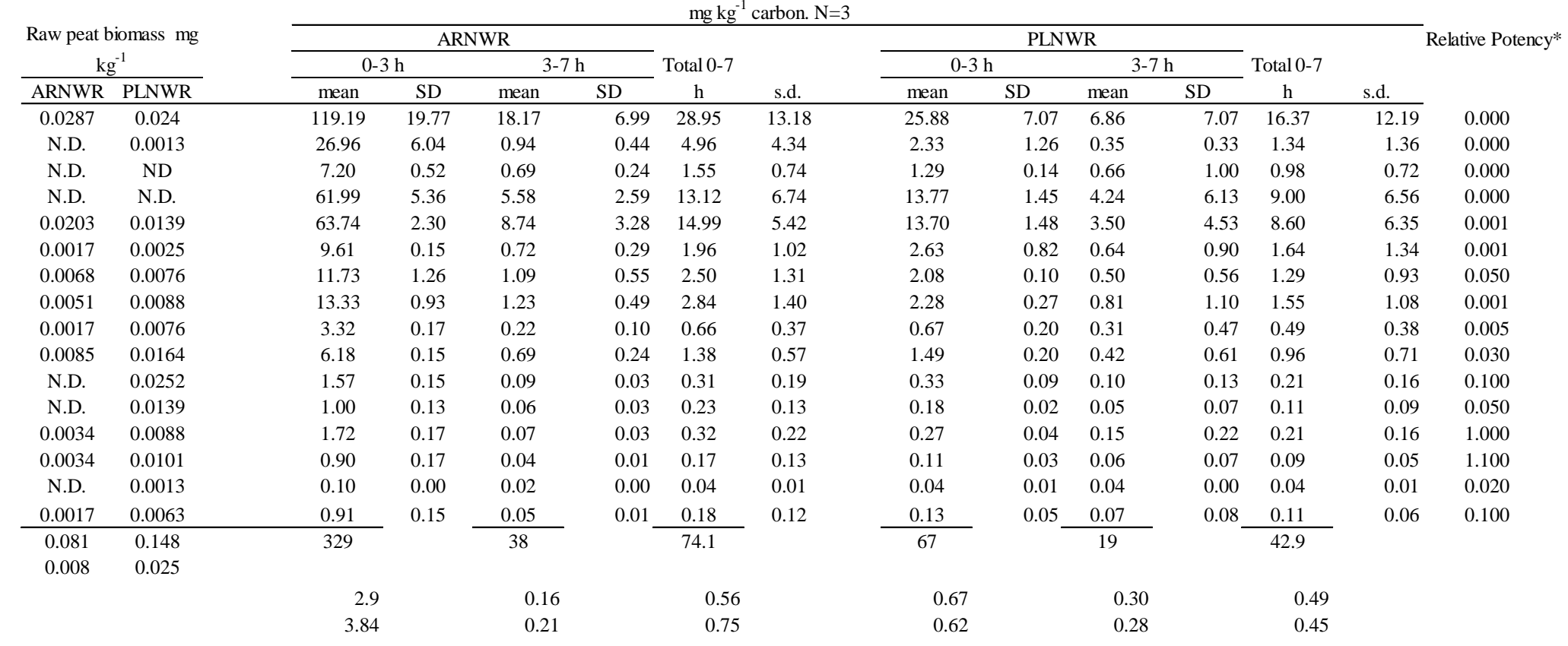

382

383 N.D. = Non-detect; PAHs in Bold are classified as reasonably anticipated human carcinogens (NTP, 2014)

$384 *$ Larsen, 1998

385 \#Raw peat mass, dried 


\subsection{PCDDs/PCDFs}

The PCDD/PCDF emission factors for AR and PL, respectively, were $2.6 \mathrm{ng} \mathrm{TEQ} / \mathrm{kg}$ and $1.9 \mathrm{ng} \mathrm{TEQ} / \mathrm{kg}$, as shown in Table 1 . These similar emission factors exist despite a higher chloride concentration (203 $\mathrm{mg} \mathrm{kg}^{-1}$ versus $112 \mathrm{mg} \mathrm{kg}^{-1}$, Table SI-1) in the raw AR biomass. These values are apparently contrary to observations previously noted for biomass combustion (Grandesso et al., 2011) where four-fold changes in $\mathrm{Cl}$ content affected PCDD/PCDF yields. The PCDD/PCDF emissions easily exceed the respective raw peat content, confirming that PCDDs/PCDFs are formed during peat combustion rather than simply volatilized (Black et al., 2012b; Black et al., 2012c).

The overall carbon-weighted emission factor of $10 \mathrm{ng}$ TEQ $\mathrm{kg}^{-1} \mathrm{C}_{\mathrm{b}}$ (not shown) is in the upper range of values observed for six prescribed and laboratory burns of pine

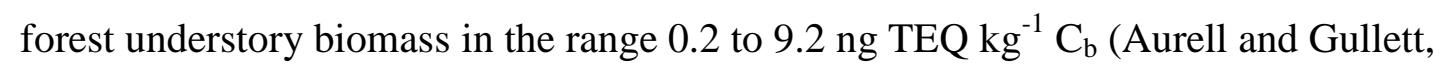
2013). This indicates that the temperatures favouring PCDD/PCDF formation (300$400{ }^{\circ} \mathrm{C}$ ) during smoldering peat burns favor PCDD/PCDF formation compared to flaming forest litter burns.

The peat PCDD/PCDF emission factor from the laboratory burns is noticeably higher than most field-measured forest litter values (Aurell and Gullett, 2013; Black et al., 2011). Indeed, the peat emission factor is significantly higher than fourteen other emission factors ranging from 0.5 to $2.5 \mathrm{ng}$ TEQ $\mathrm{kg}^{-1} \mathrm{C}_{\mathrm{b}}$ from varying biomass types (grass understory, pine forest litter, deciduous forest litter, deciduous forest) and in both field and laboratory sampling (Black et al., 2011; Black et al., 2012a).

The initial 0-3h PL samples had approximately five times higher PCDD/PCDF emission factor than the 3-7h samples (Table 1), consistent with the higher initial $\mathrm{PM}_{2.5}$, OC, and PAH emission factors (Table 1) in this work. However, this distinction was not as noticeable for the five AR samples. Higher initial PCDD/PCDF values contrast with data from laboratory forest biomass burns in which the postflame smoldering stage yielded 10-fold higher emissions per unit of carbon combusted (Gullett et al., 2008). A shift in the chemical mechanism of formation seems an unlikely explanation for these results as the duration of the burn is dominated by a constant smoldering phase. Comparison of the peat mass loss rate

16 with that of the carbon collected by the constant volume samplers appears linear (not 17 shown), suggesting little change in the mechanism of smoldering throughout the 
418 experiments. A consistent mechanism of formation supports observations of the

419 2,3,7,8-Cl-substituted congener patterns, which are relatively constant whether taken

420 in the initial or final portion of the burn (Fig. SI-4) for both AR and PL. In all

421 samples, the pattern is dominated by the OCDD and then the HpCDD congeners (Fig.

422 SI-5); when the TEF-weighted values are compared, the 1,2,3,7-8-PeCDD, 2,3,7,8-

423 TeCDD, and 2,3,4,7,8-PeCDF congeners yield, in order from highest to lowest, the

424 highest contribution to the TEQ toxicity measure (Fig. SI-6).

\subsection{Perspective}

427 A peat fire at PL NWR during the spring and summer of 2008 (the "Evans Road" 428 wildfire) impacted 16,813 ha and consumed carbon at a rate of 545 tons $\mathrm{C} /$ ha (Mickler 429 et al., 2011) with on-site estimates ranging from 200-600 tons C/ha. This carbon/area 430 consumption is higher than values reported for Scottish Highlands peat fires $(96 \pm 15 \mathrm{t}$ $431 \mathrm{C} / \mathrm{ha}$, (Davies et al., 2013)) and western Canada peat fires (21 t C/ha, (Benscoter and 432 Wieder, 2003) and $32 \mathrm{t} \mathrm{C/ha,} \mathrm{(Turetsky} \mathrm{and} \mathrm{Wieder,} \mathrm{2001)).} \mathrm{An} \mathrm{earlier} \mathrm{fire} \mathrm{in} \mathrm{the} \mathrm{PL}$ 433 NWR (1985) estimated peat burn depths up to $0.1 \mathrm{~m}$, resulting in a carbon/area 434 estimate up to $119 \mathrm{t} \mathrm{C/ha} \mathrm{(Poulter} \mathrm{et} \mathrm{al.,} \mathrm{2006).} \mathrm{This} \mathrm{fire,} \mathrm{however,} \mathrm{was} \mathrm{of}$ 435 significantly shorter duration (approximately 14 days) than the 2008 fire 436 (approximately 3 months) and likely resulted in shallower burn depths. Carbon 437 consumption is determined by the water table height and the peat composition, the 438 latter which is particularly heterogeneous on these mixed peat and mineral soils 439 ((Poulter et al., 2006)), and which offers an explanation for these widely disparate 440 carbon/area values. This range of consumption rates, when combined with the low 0$4417 \mathrm{~h}$ emission factors from each site, enabled a prediction of the emissions from the 442 Evans Road fire. Even when using the lower value of the range of carbon/area

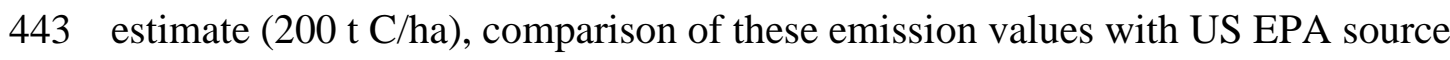
444 inventories suggests that this single peat fire contributed 4 to $6 \%$ of the annual $\mathrm{PM}_{2.5}$ 445 (EPA, 2015) and PCDD/PCDF (EPA, 2013) emissions and about 5\% of the annual 446 estimated OC emissions (EPA, 2012). 


\section{Conclusions}

450 Smoldering peat combustion was characterized by comparatively low MCE values

451 (0.80-0.88) with $\mathrm{CO}$ and $\mathrm{CO}_{2}$ levels that were generally constant throughout the

452 multi-hour burns. This pattern is distinct from combustion of other biomass where the

$453 \mathrm{MCE}, \mathrm{CO}$, and $\mathrm{CO}_{2}$ peak rapidly during the flaming phase initially, only to tail off

454 quickly after combustion of volatiles and the onset of fixed carbon combustion and

455 smoldering. Despite these seemingly static conditions, emission factors for $\mathrm{PM}_{2.5}$,

456 OC, PAHs, and PCDDs/PCDFs showed significant reductions in the second half of

457 the peat burns.

$458 \mathrm{PM}_{2.5}, \mathrm{BC}$, and UVPM emission factors in this work were much lower compared to

459 previous laboratory- and field-based biomass burning studies, perhaps due to the low

$460 \mathrm{C}$ content of our peat. Little distinction was noted between the $\mathrm{PM}_{2.5}$ emission factors

461 for the two peat sources.

462 The trend of increasing BC and UVPM with increasing MCE noted during forest

463 biomass burns was not apparent with these smoldering-dominated peat burns, as their

464 values in this work were lower and covered only a limited MCE range, below that

465 associated with flaming combustion (>0.90). The OC/EC ratios observed for this

466 work were much higher than for forest biomass burns, where higher EC values are

467 observed during prolonged flaming combustion.

468 PAH emissions were highest during the first half of the burn, resulting in emission

469 factors higher than published biomass burn results. In toxicity equivalents, emission

470 factors were consistent with other published peat and biomass data. PCDD/PCDF

471 emission factors were on the high end of the range of published values for biomass

472 combustion.

473 Calculations for a single peat fire in North Carolina using the emission factors

474 determined here showed that this single fire may have accounted for 3 to $6 \%$ of the

475 annual $\mathrm{PM}_{2.5}$ and PCDD/PCDF emissions in the U.S. and 5\% of the OC emissions.

476 While peat fires are rare compared to large forest and rangeland fires, their range of

477 emission factors, burn areas, and carbon consumption data indicate that they can be a

478 major source of air pollution suggesting additional studies to to improve the certainty

479 of emission estimates. 


\section{Acknowledgments}

482 This research was supported in part by Robert Black's appointment to the Research

483 Participation Program for the U.S. Environmental Protection Agency, Office of

484 Research and Development, administered by the Oak Ridge Institute for Science and

485 Education through an interagency agreement between the U.S. Department of Energy

486 and EPA. The research was supported primarily by the U.S. EPA; Chris Geron was

487 supported in part by the Joint Fire Sciences Program. The authors appreciate the

488 assistance of Vince Carter and Tom Crews (U.S. Fish and Wildlife Service) from the

489 Pocosin Lakes and Alligator River National Wildlife Reserves. The authors gratefully

490 acknowledge the assistance of Steve Terll, Mike Tufts, Dean Smith (ARCADIS U.S.,

491 Inc.), and Chris Pressley and Sue Kimbrough (U.S. EPA). The views expressed in this

492 article are those of the author(s) and do not necessarily represent the views or policies

493 of the U.S. EPA.

\section{References}

503 Ajtai, T., Filep, A., Utry, N., Schnaiter, M., Linke, C., Bozoki, Z., Szabo, G., and 504 Leisner, T. 2011. Inter-comparison of optical absorption coefficients of atmospheric 505 aerosols determined by a multi-wavelength photoacoustic spectrometer and an 506 Aethalometer under sub-urban wintry conditions. J Aerosol Sci 42, 859-866.

508 Aurell, J., and Gullett, B. K. 2013. Emission Factors from Aerial and Ground 509 Measurements of Field and Laboratory Forest Burns in the Southeastern US: PM2.5, 510 Black and Brown Carbon, VOC, and PCDD/PCDF. Environmental Science \& 511 Technology 47, 8443-8452. 
512 Benscoter, B. W., and Wieder, R. K. 2003. Variability in organic matter lost by

513 combustion in a boreal bog during the 2001 Chisholm fire. Canadian Journal of Forest

514 Research 33, 2509-2513.

515

Bertschi, I., Yokelson, R. J., Ward, D. E., Babbitt, R. E., Susott, R. A., Goode, J. G., and Hao, W. M. 2003. Trace gas and particle emissions from fires in large diameter and belowground biomass fuels. Journal of Geophysical Research: Atmospheres 108, 8472 .

Black, R. R., Meyer, C. P., Touati, A., Gullett, B. K., Fiedler, H., and Mueller, J. F. 2011. Emissions of PCDD and PCDF from combustion of forest fuels and sugarcane: A comparison between field measurements and simulations in a laboratory burn facility. Chemosphere 83, 1331-1338.

Black, R. R., Meyer, C. P., Touati, A., Gullett, B. K., Fiedler, H., and Mueller, J. F. 2012a. Emission factors for PCDD/PCDF and dl-PCB from open burning of biomass. Environ Int 38, 62-66.

Black, R. R., Meyer, C. P., Yates, A., Van Zwieten, L., Chittim, B. G., Gaus, C., and Mueller, J. F. 2012b. Release of native and mass labelled PCDD/PCDF from soil heated to simulate bushfires. Environ Pollut 166, 10-16.

Black, R. R., Meyer, C. P., Yates, A., Van Zwieten, L., Chittim, B. G., and Mueller, J. F. 2012c. Release of PCDD/PCDF to air and land during open burning of sugarcane and forest litter over soil fortified with mass labelled PCDD/PCDF. Atmos Environ $59,125-130$.

Chen, L. W. A., Verburg, P., Shackelford, A., Zhu, D., Susfalk, R., Chow, J. C., and Watson, J. G. 2010. Moisture effects on carbon and nitrogen emission from burning of wildland biomass. Atmos Chem Phys 10, 6617-6625.

Christian, T. J., Kleiss, B., Yokelson, R. J., Holzinger, R., Crutzen, P. J., Hao, W. M., Saharjo, B. H., and Ward, D. E. 2003. Comprehensive laboratory measurements of biomass-burning emissions: 1. Emissions from Indonesian, African, and other fuels. Journal of Geophysical Research: Atmospheres 108, 4719.

Davies, G. M., Gray, A., Rein, G., and Legg, C. J. 2013. Peat consumption and carbon loss due to smouldering wildfire in a temperate peatland. Forest Ecol Manag 308, 169-177.

Dhammapala, R., Claiborn, C., Jimenez, J., Corkill, J., Gullett, B., Simpson, C., and Paulsen, M. 2007. Emission factors of PAHs, methoxyphenols, levoglucosan, elemental carbon and organic carbon from simulated wheat and Kentucky bluegrass stubble burns. Atmos Environ 41, 2660-2669.

EPA, U. S. 1996. EPA Test Method 0023a. . SW-846 (NTIS PB88-239223), Office of Solid Waste and Emergency Response, US EPA: Washington, DC, 1996.

EPA, U. S. 1999. Compendium Method TO-9A, Determination Of Polychlorinated, Polybrominated And Brominated/Chlorinated Dibenzo-p-Dioxins And Dibenzofurans 
561 In Ambient Air. Compendium of Methods for the Determination of Toxic Organic

562 Compounds in Ambient Air, 2nd Ed EPA/625/R-96/010b,

563 http://www.epa.gov/ttnamti1/files/ambient/airtox/to-9arr.pdf, accessed April 24, 2015.

564

565

566

567

568

569

570

571

572

573

574

575

576

577

578

579

580

581

582

583

584

585

586

587

588

589

590

591

592

593

594

595

596

597

598

599

600

601

602

603

604

605

606

607

608

609
EPA, U. S. 2007. SW-846 Method 8270D, Semivolatile Organic Compounds by Gas

Chromatography/Mass Spectrometry (GC/MS).

http://www.epa.gov/osw/hazard/testmethods/sw846/pdfs/8270d.pdf, accessed April

$24,2015$.

George, I. B., R.; Geron, C.; Aurell, J.; Hays, M.; Preston, W.; Gullett, B. 2015.

Speciated gas and particulate organic emissions from laboratory peat fires. Submitted to Atmospheric Environment.

Geron, C., and Hays, M. 2013. Air emissions from organic soil burning on the coastal plain of North Carolina. Atmos Environ 64, 192-199.

Grandesso, E., Gullett, B., Touati, A., and Tabor, D. 2011. Effect of Moisture, Charge Size, and Chlorine Concentration on PCDD/F Emissions from Simulated Open Burning of Forest Biomass. Environmental Science \& Technology 45, 3887-3894.

Gullett, B., Touati, A., and Oudejans, L. 2008. PCDD/F and aromatic emissions from simulated forest and grassland fires. Atmos Environ 42, 7997-8006.

Hays, M. D., Geron, C. D., Linna, K. J., Smith, N. D., and Schauer, J. J. 2002. Speciation of gas-phase and fine particle emissions from burning of foliar fuels. Environmental Science \& Technology 36, 2281-2295.

Hosseini, S., Urbanski, S. P., Dixit, P., Qi, L., Burling, I., Yokelson, R., Shrivastava, M., Jung, H., Weise, D. R., Miller, W., and Cocker, D. 2013. Laboratory characterization of PM emissions from combustion of wildland biomass fuels. Journal of Geophysical Research: Atmospheres 118, 9914-9929.

Iinuma, Y., Brueggemann, E., Gnauk, T., Mueller, K., Andreae, M. O., Helas, G., Parmar, R., and Herrmann, H. 2007. Source characterization of biomass burning particles: The combustion of selected European conifers, African hardwood, savanna grass, and German and Indonesian peat. J Geophys Res-Atmos 112.

Jenkins, B. M., Jones, A. D., Turn, S. Q., and Williams, R. B. 1996. Emission Factors for Polycyclic Aromatic Hydrocarbons from Biomass Burning. Environmental Science \& Technology 30, 2462-2469.

Khan, B., Hays, M. D., Geron, C., and Jetter, J. 2012. Differences in the OC/EC Ratios that Characterize Ambient and Source Aerosols due to Thermal-Optical Analysis. Aerosol Science and Technology 46, 127-137.

Kim, Y. H., Tong, H., Daniels, M., Boykin, E., Krantz, Q. T., McGee, J., Hays, M., Kovalcik, K., Dye, J. A., and Gilmour, M. I. 2014. Cardiopulmonary toxicity of peat wildfire particulate matter and the predictive utility of precision cut lung slices.

Particle and Fibre Toxicology 11 (29). 
610 Larsen, J. C. L., P.B. 1998. Chemical carcinogens. In: Air pollution and health.

611 Cambridge, UK: The Royal Society of Chemistry, 33-56.

612

613

614

615

616

617

618

Liu, S., Aiken, A. C., Arata, C., Dubey, M. K., Stockwell, C. E., Yokelson, R. J., Stone, E. A., Jayarathne, T., Robinson, A. L., DeMott, P. J., and Kreidenweis, S. M. 2014. Aerosol single scattering albedo dependence on biomass combustion efficiency: Laboratory and field studies. Geophys Res Lett 41, 742-748.

May, A. A., McMeeking, G. R., Lee, T., Taylor, J. W., Craven, J. S., Burling, I., Sullivan, A. P., Akagi, S., Collett, J. L., Jr., Flynn, M., et al. 2014. Aerosol emissions from prescribed fires in the United States: A synthesis of laboratory and aircraft measurements. J Geophys Res-Atmos 119, 11826-11849.

McMeeking, G. R., Kreidenweis, S. M., Baker, S., Carrico, C. M., Chow, J. C., Collett, J. L., Hao, W. M., Holden, A. S., Kirchstetter, T. W., Malm, W. C., et al. 2009. Emissions of trace gases and aerosols during the open combustion of biomass in the laboratory. J Geophys Res-Atmos 114.

Mickler, R., Rorig, M., and Geron, C. 2011. Project Title: Predicting Prescribed and Wildland Fire Smoke, Emissions, and Fire Characteristics in Deep Organic Soils. Final Report: Joint Fire Science Program Project Number: 08-1-3-03 http://www.firescience.gov/projects/08-1-3-03/project/08-1-3-03_final_report.pdf, accessed April 24, 2015.

NTP 2014. National Toxicology Program, Polycyclic Aromatic Hydrocarbons: 15 Listings. In: Report on Carcinogens, Thirteenth Edition, Research Triangle Park, NC: US Department of Health and Human Services, Public Health Service http://ntpniehsnihgov/pubhealth/roc/roc13/ Accessed April 24, 2015.

Poulter, B., Christensen, N. L., and Halpin, P. N. 2006. Carbon emissions from a temperate peat fire and its relevance to interannual variability of trace atmospheric greenhouse gases. J Geophys Res 111.

Rappold, A. G., Stone, S. L., Cascio, W. E., Neas, L. M., Kilaru, V. J., Carraway, M. S., Szykman, J. J., Ising, A., Cleve, W. E., Meredith, J. T., et al. 2011. Peat Bog Wildfire Smoke Exposure in Rural North Carolina Is Associated with Cardiopulmonary Emergency Department Visits Assessed through Syndromic Surveillance. Environ Health Persp 119, 1415-1420.

Rein, G., Cohen, S., and Simeoni, A. 2009. Carbon emissions from smouldering peat in shallow and strong fronts. P Combust Inst 32, 2489-2496.

See, S. W., Balasubramanian, R., Rianawati, E., Karthikeyan, S., and Streets, D. G. 2007. Characterization and source apportionment of particulate matter $\leq 2.5 \mathrm{mu} \mathrm{m}$ in Sumatra, Indonesia, during a recent peat fire episode. Environmental Science \& Technology 41, 3488-3494.

Stockwell, C. E., Yokelson, R. J., Kreidenweis, S. M., Robinson, A. L., DeMott, P. J., Sullivan, R. C., Reardon, J., Ryan, K. C., Griffith, D. W. T., and Stevens, L. 2014. Trace gas emissions from combustion of peat, crop residue, domestic biofuels, 
660 grasses, and other fuels: configuration and Fourier transform infrared (FTIR)

661 component of the fourth Fire Lab at Missoula Experiment (FLAME-4). Atmos Chem

662 Phys 14, 9727-9754.

663

664 Turetsky, M. R., Benscoter, B., Page, S., Rein, G., van der Werf, G. R., and Watts, A.

665 2015. Global vulnerability of peatlands to fire and carbon loss. Nat Geosci 8, 11-14.

666 Turetsky, M. R., and Wieder, R. K. 2001. A direct approach to quantifying organic

667 matter lost as a result of peatland wildfire. Canadian Journal of Forest Research 31,

668 363-366.

669

670 Ward, D. E., Nelson, R. M., and Adams, D. F. 1979. Forest fire smoke plume

671 documentation. Proceedings of the $77^{\text {th }}$ Annualt Meeting of the Air Pollution Control

672 Association, Pap. 079-6.3, A\&WMA, Pittsburgh, PA.

673

674 Ward, D. E., and Radke, L. F. 1993. Emissions measurements from vegetation fires:

675 A comparative evaluation of methods and results, Eds. Crutzen, P. \& Goldammer, J.

676 Environmental Sciences Research Report, Vol 13, 53-76.

677

678 Woodall, B. D., Yamamoto, D. P., Touati, A., and Gullett, B. K. 2012.

679 Characterization of Emissions from Simulated Deployed US Military Waste.

680 Environmental Science \& Technology 46, 10997-11003.

681

682 Yelverton, T., Hays, M., Gullett, B. K., and Linak, W. P. 2014. Black carbon

683 measurements of flame-generated soot as determined by optical, thermal-optical,

684 direct absorption, and laser incandescence methods. Environ Eng Sci 31, 209-215.

685

686 Yokelson, R. J., Susott, R., Ward, D. E., Reardon, J., and Griffith, D. W. T. 1997.

687 Emissions from smoldering combustion of biomass measured by open-path Fourier

688 transform infrared spectroscopy. Journal of Geophysical Research: Atmospheres 102,

$689 \quad 18865-18877$.

690 